\title{
Article 20 of Japan's Constitution and Regional Integration
}

\author{
Murad Asgarov \\ Vytautas Magnus University, Kaunas, Lithuania
}

\begin{abstract}
ANNOTATION
Reinterpretation of the Japanese constitution has actual and potential impact on International Relations in the wider North East Asian region. Most research had been dedicated to the issue of Article 9, which limits Japan's military capability. The current study is going analyse Article 20 of Japan's fundamental legal document, which also has an influence on Japan's role on the international stage. Article 20 de-jure establishes that Japan is a secular state. However, with the current global trend of desecularisation, it is important to consider to what extent Japan is actually secular.
\end{abstract}

Keywords: secularism, Japan, Korea, China, Buzan.

\section{INTRODUCTION}

Article 20 of the Japanese Constitution states: "Freedom of religion is guaranteed to all. No religious organization shall receive any privileges from the State, nor exercise any political authority. No person shall be compelled to take part in any religious act, celebration, rite or practice. The State and its organs shall refrain from religious education or any other religious activity."

Investigation problem. Eurocentric approach of political studies has been mostly focused on the ways secularism is experienced in the West.

Previous research. Serbian experience with an impact of relations between state and religion on regional integration with Europe has been analysed by Blagojevic (2006) and is going to be one of the examples used for comparison in the current paper.

Novelty. Taking Article 20 as a subject of an International Relations research, as opposed to Article 9.

Aim. To analyse the role of Article 20 in Japan's relations with the rest of North East Asia.

Object. Japan's relations with the North East Asian region, namely China and Korea.

Goals. 1. Presenting the role of the state and religion relating to International Relations in order to establish a link between the chosen methodology and the subject of the study. 2. Applying the methodological framework in the case of the impact of Japan's state/religion relations on its international relations within North East Asian region.

\section{METHODS}

Content of the study, justification and description of the research methods' choice. National identity is a central component of security problems (Buzan, 1991). Buzan's amity/enmity complex, focuses on states' perceptions of each other. Four factors, which determine position of relations between countries on the spectrum are historical precedent, ideology, territory, and ethnic lines (Stone, 2009). 
Identity roots should be searched in a majority of wars. From the point of view of the Copenhagen School, security and identity reinforce each other (O’Bryan, 2011).

Ideas of other states can be manipulated internally to construct a hostile image of the "other", as it was done by the US and the USSR. Wars should be analysed through ideas or perspective of the events, rather than "historical truth". So, historical issues should be analysed as collective memory, which shapes identities. Differences in collective memories on the national level, can affect international relations. Three layers of security are: international, national, and individual. National security is the most crucial one (Buzan, 1991). So, domestic political actors, like parties and religious organisations should be considered. Thus, the current analysis is distanced from the view of states as unitary actors (Laksmana, 2013). This approach is based on the fact that Buzan calls the traditional view of International Relations theories "too restrictive". The individual layer of his analysis is correlated with the national one, as individuals can influence national security by creating organisations. An example he provides is militarised organisations with religious affiliations, such as Catholic and Protestant affiliated groups in Northern Ireland. It is going to be considered, when the Aum Shurikyo sect is discussed later. On the international level, states pose threats to each other, due to their very existence. He divides these threats on economic and military grounds that are represented by product of economic dislocation and war, respectively (Buzan, 1991).

The amity/enmity spectrum should be viewed in parallel with integration/disintegration on the regional level of security. Two or more states becoming single actors is a scenario on the radical end of the integration side of the spectrum. On the end of the disintegration end of the spectrum would be war as an

ultimate act of antagonising the other. Then there is everything in between, such as cutting or establishing diplomatic relations, participating in economic sanctions or making trade deals.

Limitations of the study. The role of religion in Japanese nationalism has influenced the given actors' actions, motivated by their interests that are shaped by their identities. So, it will primarily focus on Japanese secularism as a part of its external image, so exclusively internal issues, such as public religious holidays lie outside of the scope of the current research.

\section{RESEARCH RESULTS AND DISCUSSION}

Results. Japan has religious organisations that influence politics, like a number of "new religions" (McLaughlin, 2012). LDP had close relations with many of them, until the alliance with Soka Gakkai's Komeito (Langley Esquire, 2018). Soka Gakkai, a Nichiren Buddhist organisation, had antagonistic relations with other Nichiren Buddhist sects of Nichiren Shoushuu (Harding, 2017). The rivalling Catholic and Protestant groups in Ireland also both come from Christian basis. However, the basic Christian part of their identity did not stop them from antagonising each other like Soka Gakkai and other Nichiren organisations. In Europe, parties with religious affiliations can impact policies by entering ruling coalitions, like Christian Democratic Party of Serbia, or the Democratic Unionist Party. Catholic and Protestant groups in Northern Ireland are affiliated with parties (Harvey, 2015) and influence policies. An alliance with the government is not the only way religious organisations impact politics. An example of that is Aum 
Shunrikyo, also an organisation that influenced state policy and that it had branches in other countries, where it caused not just scandals, but even major legal cases (Radio Free Europe/Radio Liberty, 2016), shows that in this case there is a direct link between individual and international levels of security. So, there are precedents, both in the studied region and in the West for political organisations with religious affiliation (or vice versa) to have an impact outside of their own constituencies.

Buddhism and Confucianism came to Japan from China, but it is not the same Confucianism and Buddhism. There is no single Confucianism or Buddhism. A particular difference was that they did not oppose war ethos (Pyle, 2007). This makes organisations like Aum Shunrikyo be perceived as representing foreign ideologies. So, ideological factor can push Japan's relations with its neighbours towards enmity. More political freedom for such organisations can deepen this enmity even further. In parts of Europe where religiously affiliated violence is also a part of relatively recent history, like the island of Ireland and the Balkans, political organisations with religious affiliation can also lead to the same effect. When Buddhism in Japan was closely associating itself with Japanese nationalism, the difference of perception of war has been emphasised. Authors of Japanese institutional Buddhism were portraying their country as the most advanced, if not the only true Buddhist country. This idea was used to justify violence and war against those countries in Japan's neighbourhood that had to be "enlightened" due to their "backwardness". Violence for such a cause was supported by Mahayana Buddhism as acts of compassion (Victoria, 1996). The "enlightenment" was manifested in activities of religious missionary groups that were used as a tool of Japanese imperialism. Groups of all three Japanese traditional religious denominations were a part of this, as well as Japanese Christian groups. During that period, these groups found themselves in need of reconstructing their identities in order to please the dominant ideology of Japanese militarism to survive. For instance, on a congress, dedicated to creation of Association for Propagation of Japanese Confucianism, the head of State Academy of Oriental Culture, Katou Masanosuke said, quote: "Capitalists exploiting the flesh of labourers while labourers band together and strike in opposition. Landlords and tenants each wishing their own share to be large, so tenant disputes arising constantly. Politicians taking advantage of their position and yearning for unfair profits." Eventually, this sort of antagonism with capitalism was dropped by them, as in the occupied Manchuria, most capitalists were Japanese, many of whom were affiliated with the military (Paramore, 2017). So, as religious groups supported occupation, they also allowed state to intervene in their ideologies for the sake imperialist projects, which targeted Japan's North East Asian neighbours.

Historical precedence plays an important role in Confucian worldview (Lankov, 2006). In this case, historical precedence of Japanese governance and religions jointly having associations with violent acts against China and Korea are pushing relations between Japan and its neighbours towards enmity part of Buzan's spectrum. Despite the fact that Japan's religious traditions have common origins with its neighbours, the existing difference between them can be seen as sources of threats. So, organisations like Aum Shunrikyou are seen as representing foreign ideologies, even while having common East Asian roots. Reminders of association of religion and violence in Japan only reinforce this memory, which can make 
China and Korea perceive Japan more suspiciously today. This suspicion can be projected on other religious groups and traditions in Japan. Institutional Buddhism in Japan was supportive of Japanese expansion to both Korea and Northern China (Victoria, 1996). So, the territorial factor related to that issue also pushes the relations towards enmity. And the same goes for ideology and ethnic lines, as it was the ideology of Japanese nationalism, which Buddhism was fitting into. One example of that is Souen Roushi, who played a key role in exporting Zen to the West. In addition to that he also spent some time giving lectures on Zen and Japanese culture to Japanese colonial administration in occupied territories in Asia. One of the lectures he gave in Korea and Manchuria was titled "The Spirit of the Yamato Race". This sort of a sentiment, based on race in a context of military occupation clearly puts Japan and its North East Asian neighbours on enmity part of the spectrum in terms of ethnic lines factor that Buzan cites. Moreover, he openly justified Japan's military actions in Manchuria in his lectures: "War is not necessarily horrible, provided that it is fought for a just and honourable cause, that it is fought for the maintenance and realisation of noble ideals, that it is fought for the upholding of humanity and civilization. Many material human bodies may be destroyed, many humane hearts be broken, but from a broader point of view these sacrifices are so many phoenixes consumed in the sacred fire of spirituality, which will arise from the smouldering ashes reanimated, ennobled, and glorified" (Sharf, 1993). Such an attitude reinforces the difference between Japanese and other Buddhisms, as accepting such a position of Japan by its neighbours, would be going directly against their identity. The identity constructed by historical memory of territorial occupation, justified by such ideological antagonisation, which also incorporated ethnic issue.

Under traditional interpretations of the section 1 of Article 20 ("Freedom of religion is guaranteed to all'), it guarantees three freedoms that together constitute freedom of religion. These are the freedom of religious belief, the freedom of religious practice and the freedom of religious associations. The latter is then reinforced by Article 21, which deals directly with this issue (Prohl, Nelson, 2012). On March 20, 1995 (McLaughlin, 2012) Aum Shunrikyo has perpetrated a sarin gas attack in Tokyo metro, which killed 13 people (Lies, Takenaka, 2018). Naturally, such an event made question of limits of freedom of association seem more crucial, as this precedent has demonstrated that collusion of this freedom with one of the fundamental human rights, right to life is possible. This sort of collusion of rights and a question of political philosophy regarding balancing rights in a society is addressed by Buzan. According to him, life and freedom are two factors that determine security on individual level alongside with health, status and wealth. In addition to that, it is important to note that he sees state as both providing security to individuals and posing threats to them (Buzan, 1991).

Aum Shunrikyo, (or Aleph since 2000), has lost its status as a religious organisation in 1996. Two laws were passed in December 1999 by the Diet that allowed facilities of groups that have committed "indiscriminate mass murder during the past 10 years" to be monitored by authorities. Based on one of the laws, continues surveillance of the organisation is being conducted (US Department of State, 2001). For such cases, the Meiji constitution provided a limitation for religious freedom: "within limits not prejudicial to peace and order, and not antagonistic to their duties as subjects" (Prohl, Nelson, 2012). But under the 
post-War Constitution, the state had to come up with an interpretation, without having such a loophole. Consequently, by restricting the rights of Aum Shunrikyo and stripping it of its status and adopting legislation that infringes upon privacy of its members, Japan has showed its preference towards freedom of life. However, this preference is not absolute, as the organisation still exists. And given that Aum Shunrikyo had operated in other countries, this existing potential threat to freedom of life could be seen as being not just on personal or national, but also on international level. One can see for instance, an example of what Japan calls its "cultural" diplomacy, when Buddhism is being used to make connections with its neighbours. For instance, Daisaku Ikeda has had his centres launched in China, back in 2013 (Soka Gakkai, 2013). So, how is that possible, given all the negative historical memory, as well as threats, associated with organisations like Aum Shinrikyo between the two countries, concerning Buddhism?

As it was mentioned above, there is no single Confucianism or single Buddhism. It is true, that as in case of Christian Catholics and Protestants in Ireland or Aum Shinrikyo and other Nichiren Buddhist organisations in Japan, antagonisation between groups with same religious roots is possible. However, it does not constitute a rule for all of them and thus, the opposite is also possible. It is said that, Confucianism that was a part of Japanese ideological framework to occupy China is not considered representative not only of Confucianism as whole, but even of Japanese Confucianism in particular. Even if it still seen as a part of history of Confucianism (Paramore, 2017). Moreover facts, such relations with China that are enjoyed by Komeito can be attributed to the issue of the very historical memory, that contributes to animosity, which China feels towards Japan. There was a bill in the Japanese Diet to change the country's Education Law. In particular, the early draft was going to change history textbooks. They were supposed to be made a righter wing and more authoritarian. As Komeito brought the draft to Soka Gakkai's Married Woman's association, which has revised it and toned down the issue (Langley Esquire, 2018).

Such an attitude of Komeito is not an isolated incident. Given the history of their relations with the ideology of Japanese militarism, it is understandable, while their identity dictates them to oppose it. And as LDP coalition partner, they use their power to do so. This is especially evident, whenever the controversial issue of reinterpretation of Article 9 comes up in Japanese politics (Harding, 2017). So, identity of Soka Gakkai overlaps with identities of China and Korea not only due to Buddhist tradition, but also due to their experiences with Japanese militarism during the World War II. The same however, does not apply to the majority coalition partner of Komeito, the LDP. As it was mentioned, LDP maintains close relations with Shinto organisations in Japan. The current Prime Minister of the country, Shinzo Abe is a member of Shinto Association of Spiritual Leadership, which is the political branch of the Association of Shinto Shrines.

The Association unites a number of Shinto organisations with common agenda of rewriting the postwar constitution. They are particularly targeting Article 9 and have a long-time historical association with the idea of divine status of the Emperor. This status was one of the mobilising forces during the war, which makes it still relevant to Korea and China (Sieg, 2014). This connection thus challenges not only Article 9, but also Article 1 about the status of the Emperor, and article 20, as Abe being a member of the organisation 
can be interpreted as receiving a "privilege" from the state. Giving even more power to such organisation through expanding religious freedoms can push Japan towards enmity with Korea and China due to the historical memories that are associated with the issues that are being raised by them.

While the UK is not a secular state constitutionally, Serbia is. However, this is only nominal secularism, as was shown by the example of the 2000 coalitional government; parties with religious affiliations not only exist, but still can get their share of power in ruling the country. This was a part of a desecularisation process, that was going on in the country since the break-up of Yugoslavia. Later in $2000 \mathrm{~s}$, this process was only gaining strength with Vojislav Koštunica (Drezgić, 2009). So, while Japanese religious organisations are trying to either bypass constitutional norms with various reinterpretations and even potential rewriting of the constitution, in Serbia, the constitution is just being ignored. Thus, growth of political influence of religious groups as a result of reinterpretation Article 20 can have different manifestations in Japan's relations with its neighbours. These manifestations can be on the exact opposite parts of the amity/enmity spectrum, which could push or pull integration/disintegration in either way.

The existence of positive religious relations is why Japan is not hesitant to use Buddhist issues to promote its positive image abroad. This can be observed in the latest 2018 edition of Japan's Diplomatic Bluebook, where Japan supporting protection of a Buddha statue in Afghanistan, attacked by Taliban previously was presented (Ministry of Foreign Affairs of Japan, 2018). Such a policy indicates that Japan is willing to use religion in governance in attempt of improving its suspicious image abroad, which has a potential of pushing its relations with Korea and China in direction of amity. This could lead to some ideological reconciliation to an extent, thus creating a prospect for integration.

Discussion of results. The existence of organisations that influence politics in Japan can create security concerns in China and Korea. These organisations can be perceived as spreading foreign ideologies, despite having common roots. The reason for that is a different ideological pass, which the same religious traditions went through in Japan. This can push countries towards enmity with Japan, which in turn can push the countries towards disintegration.

Organisations, that can create security challenges and ideological threats, reinterpretation of Article 20 in favour of greater religious freedoms, in expense of secularism can contribute to regional disintegration. However, there are other organisations, which have positive ties in the region and that are going to enjoy these freedoms as well. So, on the one hand, reinterpretation in favour of more religious freedom can contribute to disintegration. This has to with ideology and security, and historical memories of Japanese imperialism's links with Japanese religion. These memories are also related with the territorial and ethnic aspect of Buzan's spectrum, as Japanese occupation used those links in order to justify itself. The memories can be reinforced by LDP's association with religious organisations that want to challenge the post-War Constitution. 


\section{CONCLUSIONS AND PERSPECTIVES}

On the other hand, not all religious organisations in Japan today are associated with violence, which can bring up historical negative memories. But, common religious heritage can be used to establish ties through ideological amity. This is being done by the Japanese government, as it is sending a positive message about itself in the Buddhist world. Moreover, Soka Gakkai works directly with Japan's neighbourhood by establishing its facilities in China. This shows that when it comes to such organisations, that are different from those that were supporting Japanese occupation, these memories do not play a negative role. In fact, it is the reverse, as Soka Gakkai is a factor, which supresses attempts to present those memories in a nationalistic manner, and thus tries to pull Japan's relations with North East Asia away from enmity. This pacifism also makes Soka Gakkai oppose Article 9 reinterpretation, which can help prevent regional relations go further towards enmity and disintegration.

Thus, the answer to the question "Is reinterpretation of Article 20 of the Constitution of Japan in favour of desecularisation preventing integration in North East Asia?” is both yes and no. Desecularisation as a part of a public image of a state can lead to different groups being able to acquire more political power. These groups are perceived differently in North East Asia, which will make the effects of them rising in power different.

\section{REFERENCES}

1. Acharya, A. (2007). Theoretical Perspectives on International Relations in Asia. George Washington University.

2. Bauberot, J. (2005). The Secular Principle. Embassy of France in Washington, D.C. Internet link: https://franceintheus.org/IMG/html/secularism.html [Accessed on 201812 04].

3. Blagojevic, M. (2006). Savremene religijske promene u Srbiji i proces integracije u Evropu. Filosofija I Drusvto, 1.

4. Borzel, T. A., Risse, T. (2016). The Oxford Handbook of Comparative Regionalism. Oxford University Press.

5. Buzan, B. (1991). People, States and Fear: An Agenda for International Security Studies in the PostCold War Era. Second Edition. Harvester Wheatsheaf.

6. Contreras, J., Martinez de Codes, R. M. (2013). Trends of Secularism in a Pluralistic World. Iberoamericana Vervuert.

7. Drezgić, R. (2009). Religion, Politics and Gender in Serbia: The Re-traditionalization of Gender Roles in the Context of Nation-State Formation. UNRISD.

8. Fabbri, C. M. (2005). The Constructivist Promise and Regional Integration: An Answer to 'Old' and 'New' Puzles. The South American Case. University of Warwick.

9. Green, D. (2014). The 100 Years War and the Making of Modern Europe, The Global Dispatches. Available at: http://www.theglobaldispatches.com/articles/the-hundred-years-war-and-the-making-of-modern- 
europe [accessed on 20181214$]$.

10. Harding, R. (2017). Coalition Partner Keeps Japan's Abe in Power - and in Check. Financial Times. Internet link: https://www.ft.com/content/feed704c-b31e-11e7-a398-73d59db9e399 [Accessed on 201812 09].

11. Harvey, D. (2015). Northern Ireland politics doesn't have to make your head hurt. BBC. Internet link: http://www.bbc.co.uk/newsbeat/article/32327731/northern-ireland-politics-doesnt-have-to-make-your-head-hurt [Accessed on 201812 10].

12. Laksmana, E. (2013). Realism and Non-State Actors Revisited. E-International Relations. Internet link: https://www.e-ir.info/2013/01/22/realism-and-non-state-actors-revisited/ [Accessed on 201812 09].

13. Langley Esquire. (2018). Japanese Politics 101: The Komeito Party. YouTube. Accessed on 10/12/2018. Internet link: https://youtu.be/JNIMOXeKy1I [Accessed on 201812 10].

14. Lankov, A. (2006). The legacy of long-gone states: China, Korea and the Koguryo wars. The AsiaPacific Journal, Vol. 4, 9. Internet link: https://apjjf.org/-Andrei-Lankov/2233/article.html [Accessed on $20181210]$.

15. Lies, E. and Takenaka, K. (2018). Japan Executes Leader, Six Followers, of Sarin Attack Doomesday Cult. Reuters. Internet link: https://www.reuters.com/article/us-japan-crime-sarin/several-ex-members-of-japandoomsday-cult-including-leader-executed-media-idUSKBN1JW009 [Accessed on 201812 10].

16. McLaughlin, L. (2012). Did aum change everything? What Soka Gakkai before, during, and after the aum Shinrikyō affair tells us about the persistent 'Otherness' of new religions in Japan. Japanese Journal of Religious Studies, Vol. 39, 1.

17. Mearsheimer, J. J. (1994-1995). The False Promise of International Institutions. International Security, Vol. 19, 3.

18. Ministry of Foreign Affairs of Japan. (2018). Diplomatic Bluebook 2018. MOFA of Japan.

19. O'Bryan, T. (2011). The Relation of Security To Identity. E-International Relations. Internet link: http://www.e-ir.info/2011/06/10/the-relation-of-security-to-identity/ [Accessed on 201711 29].

20. Paramore, K. (2017). Japanese Confucianism. Cambridge University Press.

21. Prohl, I., Nelson J. (2012). Handbook of Contemporary Japanese Religions. Brill.

22. Pyle, K. B. (2007). Japan Rising: The Resurgence of Japanese Power and Purpose. PublicAffairs.

23. Radio Free Europe/Radio Liberty (2016). Russia's High Court Bans Japanese Doomsday Cult Group. RFE/RL. Internet link: https://www.rferl.org/a/russia-court-bans-japanese-doomsday-cult-group/28002879.html [Accessed on 201812 14].

24. Sharf, R. H. (1993). The Zen of Japanese Nationalism. The University of Chicago.

25. Soderbaum, F., Shaw, T. M. (2003). Theories of New Regionalism: A Palgrave Reader. Palgrave MacMillan.

26. Sieg, L. (2014). Japan PM Abe's Base Aims to Restore Past Religious, Patriotic Values. Reuters. Internet link: https://www.reuters.com/article/us-japan-election-tradition/japan-pm-abes-base-aims-to-restore-past-religious- 
patriotic-values-idUSKBNOJP2E920141211 [Accessed on 201812 14].

27. Soka Gakkai. (2013). Three Daisaku Ikeda Research Centers Launched in China. Daisaku Ikeda. Internet link: https://www.daisakuikeda.org/sub/events/2013/dec/2013dec13-3-ikeda-research-ctrs-china.html [Accessed on 201812 10].

28. Stone, M. (2009). Security according to Buzan: A comprehensive security analysis. Security Discussion Papers, Series 1.

29. US Department of State. (2001). The International Religious Freedom Report for 2001. US Government Printing Office.

30. Van Wyk, J. A., Kinghorn, L., Hepburn, H., Payne, C., Chris, S. (2007). The international politics of nuclear weapons: A constructivist analysis. South African Journal of Military Studies, Vol. 35, 1.

31. Victoria, B. A. (1996). Zen and Japanese Militarism: A Critical Inquiry Into the Roots of 'Imperial Way-Zen'. Temple University.

\title{
Article 20 of Japan's Constitution and Regional Integration
}

\section{Murad Asgarov}

Vytautas Magnus University, Kaunas, Lithuania

\begin{abstract}
Object of the analysis. Influence of descularisation on integration in Northeast Asia.

Investigation problem. When it comes to the issue of secularism, Asia has been disproportionally understudied, compared to Europe. Eurocentrism in political studies has been an issue discussed by various scholars in the field. It creates a problem, represented by a gap in understanding of this topic in the global context. This makes the current case of Japan, with its ruling coalition having religious affiliations with different denominations, traditional for the country relevant for feeling this gap.
\end{abstract}

Research methods - publication data analysis, Buzan's amity/enmity spectrum.

Aim of the analysis: to establish the impact of desecularisation on countries' position within the amity/enmity spectrum

Goals of the analysis. 1. The role of the state and religion in International Relations is presented. 2. To apply the methodological framework on the case of the impact of Japan's state/religion relations on its international relations within North East Asian region.

The results of the research revealed that the impact of descularistation in Japan can push countries in the region both towards amity and enmity. There are several factors that determine countries' position on amity/enmity spectrum. Data, represented by roles of several Japanese organisations with religious affiliations was analysed by applying these factors. As various religious organisations are given more rights through reinterpretation of the Article 20, they use or abuse those rights in different ways. The issue of state/religion relations in Japan has negative historical associations in the region. To that historical memory, one can add a comparatively recent instance of Aum Shunrikyo, which created additional concerns over security threats associated with Japan-based 
religious organisations. On the other hand, Sokka Gakkai has undertaken political activities that could be seen favourably by Japan's neighbours in the very context of those same historical memories that push them towards enmity. Thus, activities of some of these organisations can lead to more amity, while of others to more enmity. Such a result shows the complexity of secularism impact on International Relations, which shows the need for its further research.

Outcomes and conclusions. With multiple different organisations acting in different ways and having different impacts, it is impossible to predict the precise impact of further desecularisation in Japan. The result however should be expected to be controversial, as major reinterpretations of one article of the constitution can be used as a precedent to justify reinterpretation of the rest of the constitution. When it comes to Article 9 in particular, that would create major political controversies both within and outside of Japan.

Keywords: secularism, Japan, Korea, China, Buzan.

Gautas 20190626

Priimtas 20191213 